\title{
5 \\ Expropriation or plunder? Property rights and infrastructure development in Oecusse
}

\section{Bernardo Almeida}

The prerogative of state institutions to expropriate property for public purposes is established by virtually all national legal frameworks, but the specificities of this power vary substantially. In line with other countries, the Constitution of the Democratic Republic of Timor-Leste (RDTL, República Democrática de Timor-Leste, in Portuguese) gives the state the possibility of expropriating property, which is often presented by politicians and state officials as an unchallengeable power. 'Whether people like it or not' (hakarak ka lakohi in Tetun) is an expression that is invoked to argue that when the state needs people's property, they must surrender it with no contestation (see Bovensiepen, Chapter 6). But is this true? Does the RDTL Constitution give the state an almost absolute power to expropriate property? And can ordinary citizens contest expropriation?

This chapter debates the legal meaning and limits of the right to property (land and existing buildings and plantations) and the power of the state to expropriate it, as established by the RDTL Constitution and infraconstitutional legislation. Although required by the constitution, the development of legal and administrative mechanisms to secure people's property rights is very limited in Timor-Leste, and a legal process for expropriations is non-existent. This is particularly relevant under the government's current development strategy - that centres on the so-called 
mega infrastructure projects - for which obtaining access to land is paramount and is happening in several areas of the country. The debate proposed by this chapter is framed around ongoing state-led processes to obtain land for infrastructure projects for the Special Economic and Social Market Zone of Oecusse (ZEESM [Zonas Especiais de Economia Social de Mercado de Timor-Leste]). This case study will show, first, the state's failure to develop mechanisms that protect and, when necessary, expropriate individual and collective rights to property and, second, how this failure is used by the state to conduct illegal dispossession.

An important postscript note must be made. In 2017, a few months after writing this chapter, a new Land Law officially called Special Regime for the Determination of Ownership of Immovable Property, and an Expropriation for Public Purposes Law were approved by Parliament. Despite some limitations, these laws are an important step towards stronger protection of people's property rights and regulation of the state's prerogative to expropriate land, but their success is dependent on a difficult process of implementation. The next few years will show whether there is a real political will to strengthening people's property rights, or if these laws are only legal artefacts with little or no meaning in practice.

\section{Right to property, expropriation and ZEESM}

In 2013, the government announced the idea of developing a ZEESM in the Timorese enclave of Oecusse (see Meitzner Yoder, Chapter 4). The government presented ZEESM as an innovative pilot project that would transform the poor and neglected Oecusse enclave into a new regional hub for trade, industry and tourism. Central to the project is the state-led construction of multiple infrastructure projects, including roads, a hotel and an international airport, with an estimated budget of over US $\$ 4$ billion for the next 20 years, one-third of which is supported by public funds. To implement this project, a vast area of land is needed - estimates range between 107 and 1,000 hectares (see Independente 2014; ZEESM 20132014: 11). In 2014, Parliament approved a new autonomous administrative status for the enclave, called the Special Administrative Region of OecusseAmbeno (RAEOA by its Portuguese acronym) to implement ZEESM (Law 3/2014, further regulated by Decree-Law 5/2015).

Infrastructure projects need land but legally obtaining access and rights to land is a difficult issue. Over three centuries of Portuguese colonialism, 24 years of Indonesian occupation, and displacement and dispossession 
caused by several waves of conflict have resulted in a complex scenario of overlapping land claims and unclear land rights (Fitzpatrick 2002). Since independence, little has been achieved in developing a property system that can clarify the validity of land titles issued by the Portuguese and Indonesian administrations, address the grievances caused by forced displacement and occupation, and clarify who has which property rights (Almeida 2016). A central point for the development of a fair property system is the legal recognition and protection of the rights of those who have never had any formal land title. Both the Portuguese and Indonesian administrations issued formal land titles, but the beneficiaries were mostly the elites close to these administrations. The great majority of Timorese have always accessed land through customary systems, characterised by complex networks of rights and obligations connected to customary groups, and have never seen their property rights recognised by state law. Under the current legal framework - especially the selectivity with which laws are interpreted and applied - they live under the real threat of seeing the land they live on, and to which they are culturally and spiritually connected, simply being classified as 'state land'.

Problems with land acquisition have contaminated the initial optimism that the population of Oecusse felt when ZEESM was announced (Rose 2016: 1; Timor Post 2015b). A preliminary ZEESM study concluded that 'almost all the land parcels [in the ZEESM area] are private land' and 'state land is negligible' (ZEESM 2013-2014: 17). This conclusion was based on the results of Ita Nia Rai ('Our Land'), a systematic land registration project from 2007 to 2012 supported by the United States Agency for International Development that registered urban parcels in the district capitals of Timor-Leste, but whose results were left in a legal limbo (Almeida 2016: 35). During the initial presentations of ZEESM to the Oecusse population in 2013, the project's main promoter stated that compensation for property rights would not be paid with money but by making land rights holders 'shareholders' of the project (Meitzner Yoder 2015: 308). This controversial idea for compensations has now been forgotten in favour of an even more controversial approach. Through an informal process and without sufficient previous consultation, written notice, adequate documentation or a clear time frame, the RAEOA administrative bodies compelled people to surrender the requested land, most of it used for housing and agriculture (Januario 2016a, 2016b, 2016c, 2016d; Meitzner Yoder 2015: 314, 2016: 1-2; Rose 2016: 2). People were offered construction materials and meagre sums of money 
to reconstruct structures built on the seized land, but at least to those without pre-independence land titles, no compensation has yet been paid. The rationale presented by the RAEOA representatives for the lack of compensation is that people without land titles are 'illegally' using the land; furthermore, the necessary legal framework to pay compensation is still missing, therefore none can be paid (Jornal Nacional Diário 2016; Timor Post 2015a). The registration conducted by the Ita Nia Rai project seems to have been ignored. The evictions proceeded without any prior social and cultural assessment or resettlement plan; in several cases, the construction materials provided were scarce and of poor quality and the money for reconstruction was insufficient to pay contracted labourers (a report from the Ombudsman's Office details some of these problems see Provedoria dos Direitos Humanos e Justiça 2016). Many families have ended up living in tents or improvised shelters (Meitzner Yoder 2016: 2 ). There are also reports of people being threatened with the use of police force (Jornal Nacional Diário 2015). Rose (2016: 2) reports one case in which the land users managed to resist eviction and get some compensation from the construction company, but this seems to be an exception. Land has been taken for various projects, including widening of roads, an airport and a hotel constructed by the RAEOA. Future projects will require more land.

Interestingly, as in the case of Suai (detailed in this volume by Bovensiepen), the power of the state to take land for all kinds of purposes goes almost unquestioned both by state officials and the people affected. The debate is mostly centred on compensation and the lack of due process. In Oecusse, the lack of compensation for land was compared with the case of Suai, where US\$3 per square metre were paid to land claimants, independent of whether or not they had land titles. The president of the RAEOA stated that if the affected people - most of them subsistence farmers - wanted to get compensation, they should appeal to the courts (Jornal Nacional Diário 2016). But with little knowledge about their rights and obligations in this process, no financial capacity to hire a qualified lawyer and no state legal aid offered to them, it is very unlikely that this problem will ever be analysed by a court. Furthermore, as the case of Suai well exemplifies, the payment of compensation to the affected people is often not enough to avoid the social problems caused by expropriation.

This case study raises the question: was the Authority of the RAEOA legally entitled to dispossess these people the way it did or was it, in fact, an act of plunder? 


\section{The legal framework for property rights and expropriation in Timor-Leste}

\section{The right to property in international law}

The Universal Declaration of Human Rights (UDHR) from 1948 is the starting point for the protection of the right to property in modern international law. Despite not being a treaty, UDHR assumes a central role in the protection of human rights, and it is often referred to by scholars and practitioners as part of customary international law (constant and uniform practice of states). It is, therefore, a primary source of international law (Hannum 1996; Jacobs 2013: 91). Article 17 of UDHR, establishing the right to property, is central to this legal analysis. This right is divided into two points: (1) 'Everyone has the right to own property alone as well as in association with others'; and (2) 'No one shall be arbitrarily deprived of his property'. The drafting of this article was difficult and controversial, due to opposing political views of property (Jacobs 2013: 91; Dehaibi 2015: 17). The final text of article 17 is vague as result of this controversy, and the meaning and limits of the right to private property are still debated by academics and legal jurisprudence (Dehaibi 2015: 13; Golay and Cismas 2010: 11).

It is easiest to start by determining what the right to property is not. First, the right to property established in article 17 is not limited to individual rights to property but also includes collective rights (Golay and Cismas 2010: 3). This idea is relevant in contexts such as Timor-Leste, where collective forms of rights to property are widespread. Second, article 17 does not recognise unrestricted rights to property; however, limits can be imposed without an agreement between authors on where those limits should be placed (Dehaibi 2015: 17). While authors seem to agree on these two points, they do not significantly clarify the meaning of article 17. A strict interpretation sees the right to property as a right of individuals to keep the property already obtained by law but without any positive obligation of the state to provide property (Jacobs 2013: 97). Contrary to this view, some authors have called attention to the fact that protection of the right to property is not an end in itself but an instrument to protect human rights and achieve the self-realisation preconised by UDHR (Dehaibi 2015: 19; Joireman and Brown 2013: 168). Authors have pointed out at least three different perspectives on this instrumental role 
of property rights. Some have focused on the economic value of property as a way of protecting the human rights of the poorest (Commission on Legal Empowerment of the Poor and UNDP 2008: Chapter 2). Others have framed the right to private property as an intrinsic part of the right to an adequate standard of living, closely connected with the right to housing and food (Golay and Cismas 2010: 23). Finally, other authors maintain that some property has an intrinsic personal value for some people, and obtaining rights over that property is fundamental for their personhood and identity (Dehaibi 2015: 19; Joireman and Brown 2013: 166; Radin 1994: 71). Although coming from different perspectives, these three positions imply an active role of the state in legislating and acting to substantiate the two principles of the right to property; in other words, creating an enabling environment for fulfilling the right to property.

Ironically, the right to property is not part of the International Covenant on Economic, Social and Cultural Rights (ICESCR) from 1966 (Golay and Cismas 2010: 3). However, the right to property is implicit in the right to adequate housing established in article 11 of ICESCR. According to the General Comment No. 4 of the UN Committee on Economic, Social and Cultural Rights, legal tenure security is one of the criteria that defines adequate housing, and forced evictions can only proceed in very exceptional circumstances.

Furthermore, the right to property is part of key human rights treaties that Timor-Leste is signatory to, such as the international Convention on the Elimination of All Forms of Discrimination against Women from 1979 (ibid.: 4). The right to property and the right of states to expropriate it is further detailed by several soft-law instruments, such as the Basic Principles and Guidelines on Development-based Evictions and Displacement, the Association of Southeast Asian Nations (ASEAN) Human Rights Declaration, and the Voluntary Guidelines on the Responsible Governance of Tenure of Land, Fisheries and Forests in the Context of National Food Security.

Understanding the right to property in international law is fundamental to understanding the Timorese legal framework. The RDTL Constitution incorporates into the national legal framework all international treaties and agreements that Timor-Leste is party to, as well as customary principles of international law that prevail over national law (articles 9.1, 9.2 and 9.3 of the Constitution). As a result, international law sets the boundaries of the Timorese legislation and can be directly used in 
court, against or in absence of national law (Vasconcelos 2011: 52). Furthermore, the constitution incorporates UDHR as an interpretative element of the fundamental rights it prescribes. According to article 23 of the RDTL Constitution, the '[f] undamental rights enshrined in the Constitution ... shall be interpreted in accordance with the Universal Declaration of Human Rights' (ibid.: 91).

In conclusion, article 17 of UDHR is central to understanding the right to property in the Timorese legislation. While the interpretation of this article is contentious, it is the author's view that this article obliges states to actively create the necessary conditions to guarantee the right to property, especially when this right is necessary to enforce other human rights. This obligation is especially strong when housing is at stake.

\section{The right to property in the RDTL Constitution}

This section analyses the right to property in the RDTL Constitution. This analysis divides the right to property into two parts: (1) the right to obtain and enjoy property; and (2) the right of the state to expropriate property.

\section{The right to obtain, enjoy and transfer property}

Article 54.1 of the RDTL Constitution establishes the basis for the right to property by determining that '[e]very individual has the right to private property and can transfer it during his or her lifetime or upon death, in accordance with the law'. While the second part of this article is straightforward, the first part follows an equivalent formulation of article 17 of UDHR, recalling the above-mentioned debate: Does the article simply create a state obligation to recognise existing rights to property, or does it represent a larger obligation to actively provide these rights?

Different methods of legal interpretation can help to answer this question. The first interpretative method is established by the RDTL Constitution: fundamental rights should be interpreted in light of UDHR. As debated above, article 17 of UDHR obliges states to provide rights to property; therefore, the same should be considered for article 54.1 of the Constitution.

This argument can be further strengthened by other methods of interpretation. A historical interpretation based on the minutes and documents of the Constituent Assembly in 2001 (available in the 
Parliament archives) do not give much information about the origins and intentions of this article. Nevertheless, it is possible to see in these minutes a clear concern among members of the assembly to create a legal framework that can equitably address the injustices regarding legal rights to land left by colonialism and occupation (see also Devereux 2015: 246-254).

A systematic interpretation based on other articles of the RDTL Constitution can also help to clarify article 54.1. First, article 54.2 establishes that ' $[\mathrm{p}]$ rivate property should not be used to the detriment of its social purpose'. This provision can have several interpretations. During the Indonesian occupation, the concept of 'social function' of the land was used to justify unfair dispossession by the state (Plessi and Leckie 2000: 7), one of the main concerns raised in 2001 by members of the Constituent Assembly (Devereux 2015: 250, 252). Furthermore, the prerogative of the state to take land from individuals is regulated in article 54.3. As such, the purpose of article 54.2 is not to justify any dispossession by the state. There are at least two other interpretations of this article: the first is to see it as a limit to the right to property, establishing that this right is not absolute and that the state can impose limitations on the use of property in order to safeguard collective interest - for example, restrictions on construction in protected areas (see Almeida 2016: 12; Vasconcelos 2011: 224). The second interpretation of this article is to see it as a guideline for the property system, determining that it should promote the reduction of inequalities in the distribution of wealth and income (compare with Miranda 2000: 526). These two interpretations do not exclude each other and both can be applied.

Article 141 should also be considered for the systematic interpretation of article 54.1. This article establishes that '[o]wnership, use and useful possession of land as one of the factors for economic production shall be regulated by law'. With economic production in view, this article again stresses the need for the state to develop and implement an adequate property system. Finally, article 2.4 of the RDTL Constitution determines that ' $[\mathrm{t}]$ he state shall recognise and value the norms and customs of Timor-Leste that are not contrary to the Constitution and to any legislation dealing specifically with customary law'. As debated above, de facto customary systems regulate access to land for the great majority of Timorese. In light of this provision and in line with the previously analysed articles, there is an obligation - under the limits of the Constitution - to accommodate those customary systems into the property system. Finally, 
considering the debate around article 17 of the UDHR, and the role of the UDHR as a source of constitutional interpretation, it is clear that article 54.1 of the Constitution encompasses individual but also collective forms of ownership.

In conclusion, the first part of article 54.1 of the RDTL Constitution can be interpreted to mean various things. First, it can be interpreted as obliging the state to respect and protect the rights to property of those whose rights are already recognised by law. Second, it can be interpreted as the right of everyone to obtain rights to property and, once those rights are obtained, the right to use and enjoy that property. Third, this article can be interpreted as an obligation of the state to develop and implement the legal and administrative mechanisms to protect property rights not yet recognised by law. The range of rights to be protected is bound by the need to respect other fundamental rights, such as the right to adequate housing, the reduction of social inequalities, the respect for customary norms that do not contradict the constitution and the use of property as an economic factor. These three interpretations are not mutually exclusive; indeed, in the author's view, the first part of article 54.1 includes all of them. As a result, the lack of an adequate and functioning property system as described in the above case study represents a clear situation of unconstitutionality by omission. Thus, the constitution recognises the property rights of the people affected in the ZEESM case study, despite the state's failure to substantiate these rights. If by law people have these property rights, the state can only take them through an expropriation. The next section considers in which cases expropriation can legally happen.

\section{The right of the state to expropriate property}

Expropriation limits the right to property. Expropriation allows the state to acquire rights over property, against the will of the holder of that right, for reasons of public interest (Fonseca 2011: 10). The premise that justifies expropriation is that in some cases it is reasonable to disturb the right of one individual in order to provide a larger benefit to the community (Ronen 2013: 249). The right to expropriate encompasses two main questions: (1) In which situations can property be expropriated; and (2) Who has the authority to expropriate? When the right to expropriate can be exercised, a third question surfaces: (3) What is fair compensation? Expropriation should not be confused with situations of 'confiscation' in which private property is seized as a fine or forfeit, or 'nationalisation', in which a private business is taken by a government (Reeves 1969: 867). 
Expropriation is regulated by article 54.3 of the RDTL Constitution. The initial text proposed by the political party, Fretilin, to the Constituent Assembly determined that ' $[\mathrm{r}$ ] equisitioning and expropriation of property can only take place in accordance with the law'. In this text, the limits of expropriatory power would be solely dependent on subsequent legislation. After the initial debates in 2001, a more detailed article including 'public interest' and 'compensation' was drafted (Devereux 2015: 247, 251). In the final plenary meetings after public consultation, the criterium of 'fair' compensation was added (Devereux 2015: 254). The final text of article 54.3 became the following: 'Requisitioning and expropriation of property for public interest shall only take place following fair compensation in accordance with the law'. As such, article 54.3 establishes three requisites for an expropriation: Expropriation can only happen (1) in the public interest, (2) upon the payment of fair compensation, and (3) according to the law. The following paragraphs analyse each requisite.

While the concept of 'public interest' is central to expropriation, the RDTL Constitution does not define it. This problem is not unique to Timor-Leste, and academics and practitioners have recorded various cases worldwide of unfair dispossession by the state based on unclear definitions of the public interest (Cotula 2013; Lund 2008). Those expropriations where 'economic development' is used to justify the public interest are especially controversial, and even more so if the beneficiary of the expropriation is a private party (Eisenberg 1995: 220; Wolford et al. 2013). For instance, Levien (2013) describes in detail how expropriation for private investment in special economic zones in India became a mechanism of making the poorest citizens subsidise investments that mostly benefited the investor elites. In 2005, the case Kelo vs City of New London, in which the Supreme Court of the United Sates allowed an expropriation of a private owner to another private owner for economic development, resulted in a strong movement against this kind of expropriation and, since then, many states have approved legislation that specifically prohibits it.

Although the RDTL Constitution does not define public interest, systematic and comparative interpretation can help to clarify this concept. First, the Indonesian law for voluntary land acquisition (not expropriation), in force before Timor-Leste's independence, provides a detailed list of infrastructure considered to have a public interest (article 5 of Presidential Decision No. 55/1993). Second, legal doctrine identifies some minimum principles that limit the concept. The first principle is that the general public should be the main beneficiary of the expropriation (Eisenberg 
1995; Ronen 2013: 249). The expropriation can bring side benefits to individuals (for example, land values in a certain area go up because of new infrastructure), but the core beneficiary should be the general public. Proportionality is the second guiding principle that should define what is considered public interest; the benefit to the public should be bigger than the damage caused to individuals whose property is expropriated (Vasconcelos 2011: 94, 96, 203). Finally, the expropriation can only happen when there is no other viable alternative (ibid.: 94, 97; to compare, see Fonseca 2011: 15). Also, and in line with the above-mentioned debate about land as an element of personal identity, some authors sustain that the threshold of 'public interest' should be even stricter in cases of indigenous peoples' land rights (Golay and Cismas 2010: 16). As debated below, compliance with these principles must be justified in each case. Going back to the case study in Oecusse, we can ask whether the purposes for which property was taken fit the concept of public interest. Some, such as the hotel, raise serious doubts. What are their advantages for the general public? Are those advantages superior to the damage caused to individuals? Was there no viable alternative for those projects? The people affected by expropriation have the legal right to know what purpose the expropriation serves and to contest it. The expression 'hakarak ka lakohi' ('whether you like it or not') makes less sense when seen in the light of the law; people have the right to refuse and contest expropriation.

The second requisite for expropriation imposed by the RDTL Constitution is fair compensation. Determining fair compensation is not easy and starts with the kind of compensation to be paid: money or replacement property - would this include shares in a company, as originally proposed by ZEESM? Other problems come with 'market value' solutions: what is the monetary value of property in an area where it is not transacted with money (for example, as in Timor-Leste, where often land is transacted inside customary groups, as part of long-term relationships)? Finally, how should things without monetary value be compensated for (for example, the sentimental value of the land; the social or ancestral connections lost with resettlement)? The minutes of the Constituent Assembly of 2001 show how, in light of all the unfair dispossessions experienced during the Indonesian occupation, the assembly was committed to adding 'fair' in the requisite of compensation, but no concrete principle was written in the Constitution. A reduced budget is sometimes used by Timorese state officials to justify low compensations. This justification is based on a misconception of expropriation. The idea behind expropriation is 
not that those unfortunate enough to be in the path of a public interest project have to contribute their property to the common good. The only imposition on those affected by an expropriation is that they agree on transacting the property. The costs of that transaction - the value of their right to property, the resettlement costs, the disturbance caused - are a burden on the public, not the affected individuals, and should be factored into the costs of undertaking the project that the expropriation serves (Fonseca 2011: 21). Therefore, compensation should fully compensate the affected people and leave them in at least an equal economic and social position as the one they had before expropriation.

Finally, article 54.3 establishes that expropriation should happen in accordance with the process regulated by law (Almeida 2016: 13; Oliveira et al. 2015: 521; Vasconcelos 2011: 203). Legally speaking, expropriation is a complex process, composed of several administrative acts, such as the decision to expropriate, the declaration of public interest and the determination of compensation (Guerreiro 2012: 18, 20). As with any administrative act, these are bound by several principles (for example, legality, transparency) and obligations, such as to justify the legal and factual grounds on which the administrative acts are taken (ibid.). The sequence of and specificities on these acts need to be detailed by law. Furthermore, it is paramount that the law defines which institutions have the power to perform each of these administrative acts. The principle of legality determines that public institutions can only carry out the administrative acts that the law explicitly authorises them to practise (ibid.: 6). In conclusion, the obligation of having a clear administrative process is not just a whim or a bureaucratic formality; it is these formalities that will give people the opportunity to participate in the decision to expropriate, to contest the foundations of the expropriation and to fight for better compensation (see Fonseca 2011: 12). These formalities are also necessary to assess whether an expropriation process respects the abovementioned principles.

As will be described in the next section, the general legal framework set by the RDTL Constitution has experienced very limited development in infra-constitutional legislation. 


\section{The infra-constitutional legal framework}

This section analyses the right to private property in the Timorese infraconstitutional legal framework. The right to obtain and enjoy property is only briefly analysed, while the right of the state to expropriate is debated in more detail.

\section{The right to obtain, enjoy and transfer property}

Timor-Leste does not yet have a consolidated property system that can address past grievances and protect its citizens right to property (see Almeida 2016). If those with formal land titles from Portuguese and Indonesian administrations are uncertain of the legal validity of their rights, those without a formal land title - the great majority are in a worse situation. Under the incipient infra-constitutional legal framework, even those with clear and deep customary connections to property run the risk of having their property classified as state land.

The Decree-Law 5/2015 that regulates RAEOA says that it has the power to administer the property cadastre of Oecusse (article 8.1[c]), but does not clarify which RAEOA administrative body has this power. In practice, there is no property cadastre functioning in Oecusse. In conclusion, the state is failing to create the legal framework to substantiate the property rights protected by the RDTL Constitution.

\section{Expropriation}

The RDTL Constitution requires that expropriation follow an administrative process predetermined by law. However, since TimorLeste's independence in 2002, no expropriation law has been approved. The Indonesian law in force before 25 October 1999 was integrated into the Timorese legal system as subsidiary legislation and, therefore, the Indonesian Expropriation Law in force at that time is, in theory, still applicable (Almeida 2017: 176). However, the disconformity of this law with the current Timorese institutions and administrative practices makes its implementation in Timor-Leste very difficult, if not impossible. The Indonesian legal framework also has legislation for voluntary land acquisition by the state that could guide a pre-expropriation process of negotiation and acquisition of land (Presidential Decision No. 55/1993). However, this process has also been ignored. 
Despite the lack of a general expropriation law, Law 3/2014, which created ZEESM and RAEOA, briefly mentions expropriation in article 27. However, this article does not have any procedural rules for expropriation and only adds to the confusion. Article 27.1 establishes that:

the Authority [of the RAEOA] protects, according to the law, the right of the individual and collective/legal persons to acquire, use, transfer, and transfer by inheritance property, and the right to receive compensation in case of expropriation.

Such provision does not add any depth to what is established in articles 54.1 and 54.3 of the RDTL Constitution. Article 27.2 establishes that:

[t]he value of compensation mentioned in the previous article should correspond to its real value at the moment of the expropriation, and should be freely convertible and paid without unjustifiable delay.

The expression 'real value' seems to refer to the market value of the property, but is not consistent with terminology commonly used by land evaluators. However, as debated above, market value raises problems in places where an open property market does not exist, such as Oecusse. The second part of this article is even less clear: what is freely convertible compensation, to be converted into what? What is an 'unjustifiable delay'? Article 27.3 establishes that ' $[\mathrm{t}$ ] he property rights of companies and investments from outside of the Region are protected by law'. While this article was probably drafted to assure foreign investors that their assets would not be arbitrarily expropriated, it does not add any more detail to what was already established in article 54 of the constitution.

Expropriation is also mentioned by Decree-Law 5/2015, which further regulates RAEOA. Article 6.1(f) establishes that the RAEOA administrative bodies are allowed, according to the competencies given to them by law, to conduct 'expropriation[s] verified as being in the public interest, under the terms established by law'. However, the attribution of this competency to the RAEOA administrative bodies has a number of problems. First, the constitutionality of article 6.1(f) is dubious: article 96.1(1) of the RDTL Constitution establishes that the government needs authorisation from Parliament to make decree-laws about 'means and ways of ... expropriation ... on grounds of public interest, as well as criteria for the establishment of compensations in such cases'. Article 6.1(f) of the decree-law gives RAEOA administrative bodies the power to expropriate, which is part of the 'means and ways of expropriation'; however, this 
decree-law was not preceded by legislative authorisation, which makes this article unconstitutional. Second, neither this decree-law nor any other legislation specifies which administrative bodies are competent to order an expropriation. As debated above regarding the principle of legality, the competency to practise acts cannot be presumed - it must be specifically determined by law. Furthermore, note that article 6.1(f) specifically mentions the power of the RAEOA administrative bodies to expropriate 'within the strict limits of the competencies given [to them]'. Therefore, there is currently no RAEOA administrative body with the power to order an expropriation. Furthermore, article 52.6(a) refers to the possibility of certain 'development companies' becoming beneficiaries of expropriation. Third, similar to article 54.3 of the constitution, article $6.1(\mathrm{f})$ of the decree-law establishes that expropriation should happen according to the law. However, as shown above, there is no law detailing the expropriation process. In conclusion, the authority given to the RAEOA administrative bodies to expropriate property has a very dubious constitutionality and, under the current legal framework, cannot be applied.

Another detail of Decree-Law 5/2015 deserves mention. Article 2.2 establishes that the decisions of RAEOA executive bodies have to be recorded in writing and adequately justified. Also, article 39.1 establishes that the decisions of the RAEOA Authority and its president detailed in article 35 and 36 have to be published in the first series of the Official Journal (Jornal da República), and the lack of publication makes these decisions legally inapplicable (see also article 40[a]). Until now, no publication about expropriations has ever been made in the Official Journal. Hence, it is safe to say that no legal expropriation was ever conducted in RAEOA.

We can, therefore, conclude that the infra-constitutional legislation necessary to conduct an expropriation is not in place and that the references to expropriation in the laws that govern ZEESM and RAEOA do not address this gap. Furthermore, the article that gives the RAEOA administrative bodies the power to expropriate property is unconstitutional. It is safe to say that the RAEOA administrative bodies did not access land in Oecusse through expropriation according to the constitutional criteria. 


\section{Conclusion}

The RDTL Constitution and the international law that compose the Timorese legal framework demand legal and administrative mechanisms that can effectively protect the right to property. The exact scope of this obligation is not clear, but the protection of the right to housing, food and self-identity, as well as the objective of reducing inequality, should guide those mechanisms. Within the limits imposed by the constitution, the de facto customary property systems that rule most of the country must be acknowledged and be part of these mechanisms. However, in practice, little has been achieved in establishing these legal and administrative mechanisms.

By law, expropriation can only be used for clear public interest, upon payment of fair compensation and in accordance with a pre-established legal process. The necessary infra-constitutional legal framework is not yet in place, and the reference to expropriation in the RAEOA legislation does not provide any procedural guidance. Furthermore, the attribution of competency for expropriation to the RAEOA administrative bodies is unconstitutional in its current format.

The Oecusse case study shows that, despite the failure in protecting property rights, and despite not creating the necessary mechanisms for expropriation, state institutions are moving forward with infrastructure projects. Worse, these failures are deliberately used by these state institutions, together with a selective use of the law, to justify illegal dispossession. The affected people have no real means to challenge the legality of dispossession. As in other cases, politicians justify this disrespect of the law by invoking the country's young independence, the need to create jobs and the demands of economic development. State institutions cannot cherry-pick the 'rights' that the RDTL Constitution gives them and forget the obligations that come with the exercise of those 'rights'. The legitimacy of state institutions is based on the powers given to them by the constitution, and these powers are limited by clear obligations (for example, expropriation should be based on a process established by law), and clear regulations for exceptional situations (for example, article 24 about restrictive laws). By not respecting these obligations, state institutions undermine their own legitimacy and the rule of law principles established in the Constitution. In other words, they break what Canotilho (2003: 253) called the 'the chain of legal legitimacy' (see also Oliveira 
et al. 2015: 345). When economic development or job creation is used to justify the disrespect of the Constitution's basic rules, as has happened in the Oecusse case study, a very dangerous precedent is set.

In the face of the total disarray in which property rights and state administration were left after the violence and destruction that followed the 1999 popular consultation, one could not expect that, at this point in time, the country would have perfect mechanisms for determining land rights and conducting expropriations. But it is the obligation of the state to not proceed with infrastructure projects without the minimum legal basis to implement them. For instance, if the mechanism for identifying property owners is not in place, everyone residing in the affected area should be compensated as owners. Moreover, the situation of TimorLeste is not unique, and there are many lessons to be taken from other developing countries. More than on infrastructure, the development of Timor-Leste depends on respecting the rights of its people.

As mentioned in the introduction, a new Land Law and Expropriation for Public Purposes Law were approved a few months after the writing of this chapter. Despite some limitations, these laws provide a stronger legal framework than previously existed for protecting people's property rights and regulating the prerogative of the state to expropriate land, but the success of these laws will be dependent on a complex process of implementation. Nevertheless, the laws are now in force, and 'waiting for the law' is no longer a reason for not recognising people's rights to the people. The next years will show whether there is a real political will to strengthen people's property rights in Timor-Leste.

\section{References}

Almeida, B. (2016) Land tenure legislation in Timor-Leste, Leiden: Van Vollenhoven Institute, The Asia Foundation.

Almeida, B. (2017) 'The main characteristics of the Timorese legal system a practical guide', Verfassung und Recht in Übersee VRÜ, vol. 50, pp. 175-187. doi.org/10.5771/0506-7286-2017-2-175.

Canotilho, J. J. G. (2003) Direito constitucional e teoria da constituição [Constitutional law and constitutional theory], 7th edition, Coimbra: Almedina. 
Commission on Legal Empowerment of the Poor and UNDP (2008) Making the law work for everyone, vol. 2, Working Group Reports. Available at: www.undp. org/content/dam/aplaws/publication/en/publications/democratic-governance/ legal-empowerment/reports-of-the-commission-on-legal-empowerment-of-the -poor/making-the-law-work-for-everyone---vol-ii---english-only/making_the_ law_work_II.pdf.

Cotula, L. (2013) The great African grab? Agricultural investments and the global food system, London: Zed Books.

Dehaibi, L. (2015) 'The case for an inclusive human right to property: Social importance and individual self-realization', Journal of Legal Studies, vol. 6, no. 1 , article 5. Available at: ir.lib.uwo.ca/cgi/viewcontent.cgi?article $=1159 \&$ context=uwojls.

Devereux, A. (2015) Timor Leste's Bill of Rights: A preliminary history, Canberra: ANU Press. doi.org/10.22459/TLBR.05.2015.

Eisenberg, A. (1995) "Public purpose" and expropriation: Some comparative insights and the South African Bill of Rights', South African Journal on Human Rights, vol. 11, no. 2, pp. 207-221. doi.org/10.1080/02587203.1995. 11827560 .

Fitzpatrick, D. (2002) Land claims in East Timor, Canberra: Asia Pacific Press.

Fonseca, G. da (2011) 'A expropriação por utilidade pública, o poder político e a Constituição' ['Expropriation for public interest, the political power, and the Constitution'], Revista do Ministério Público, vol. 126, April/June, pp. 9-25.

Golay, C. and Cismas, I. (2010) Legal opinion: The right to property from a human rights perspective. Available at: papers.ssrn.com/sol3/papers.cfm?abstract_id= 1635359.

Guerreiro, S. (2012) Colectânea de direito administrativo Timorense com comentários de conteúdo Parte II - Actividade administrativa em Timor-Leste [Compilation of Timorese administrative legislation with comments on its content - Part II: the administrative activity in Timor-Leste]. Provedoria de Direitos Humanos e Justica, UNDP.

Hannum, H. (1996) 'The status of the Universal Declaration of Human Rights in national and international law', Georgia Journal of International and Comparative Law, vol. 25, no. 1, pp. 287-397. Available at: digitalcommons. law.uga.edu/gjicl/vol25/iss1/13/.

Independente (2014) 'Projetu ZEESM Oekusi okupa rai ektare rihun ida' ['The Oecusse ZEESM project occupies 1,000 hectares of land'], 28 April. 
Jacobs, H. M. (2013) 'Private property and human rights: A mismatch in the 21 st century?', International Journal of Social Welfare, vol. 22, S85-S101. doi.org/10.1111/ijsw.12044.

Januario, R. (2016a) 'Catarina: Hau laiha kbiit hodi koalia, hau pasensia ho situasaun ida ne'e' ['I'm not able to express my patience with this situation'], Rede Ba Rai, 2 June. Available at: redebarai.org/?p=304 (site discontinued).

Januario, R. (2016b) 'Francisco Salu: Hau nia esperansa mohut' ['My hope is dead'], Rede Ba Rai, 2 June. Available at: redebarai.org/?p=310 (site discontinued).

Januario, R. (2016c) 'La fo valor ba maluk alezadu [sic.] hodi moris justu' ['Not giving value for disabled friends to live fairly'], Rede $B a$ Rai, 2 June. Available at: redebarai.org/?p=300 (site discontinued).

Januario, R. (2016d) 'Marius Fuca: Sistema fahe material la transparansia' ['The system to disburse materials isn't transparent'], Rede Ba Rai, 2 June. Available at: redebarai.org/?cat=6 (site discontinued).

Joireman, S. F. and Brown, J. (2013) 'Property: Human right or commodity?' Journal of Human Rights, vol. 12, no. 2, pp. 165-179. doi.org/10.1080/147 54835.2013.784662.

Jornal Nacional Diário (2015) 'Presiza espasu ba projetu autoridade justifika desizaun - ZEESM muda povu ho forsa' ['Authority justifies the decision that they need land for the project - ZEESM uses force to move people'], 9 October.

Jornal Nacional Diário (2016) 'Alkatiri: Kompensasaun laos atu sai riku' ['Alkatiri: compensation is not to get rich'], 13 June.

Levien, M. (2013) 'Regimes of dispossession: From steel towns to special economic zones', in Wolford, W., Borras Jr., S. M., Hall, R., Scoones, I. and White, B. (eds) Governing global land deals: The role of the state in the rush for land, Milton, QLD: Wiley-Blackwell (Kindle version). doi.org/ 10.1002/9781118688229.ch9.

Lund, C. (2008) Local politics and the dynamics of property in Africa, New York: Cambridge University Press. doi.org/10.1017/cbo9780511510564.

Meitzner Yoder, L. S. (2015) 'The development eraser: Fantastical schemes, aspirational distractions and high modern mega-events in the Oecusse enclave, Timor-Leste', Journal of Political Ecology, vol. 22, pp. 299-321. doi.org/ $10.2458 / \mathrm{v} 22 \mathrm{i} 1.21110$.

Meitzner Yoder, L. S. (2016) Oecusse's special economic zone and local governance, SSGM In Brief 2016/5, Canberra: State, Society \& Governance in Melanesia, ANU. Available at: dpa.bellschool.anu.edu.au/sites/default/files/publications/ attachments/2016-04/ib-2016-5-meitzneryoder.pdf. 
Miranda, J. (2000) Manual de direito constitucional, tomo IV: Direitos fundamentais [Constitutional law manual, part IV: Fundamental rights], 3a Edição, Coimbra: Coimbra Editora.

Oliveira, B. N., Gomes, C. and Santos, R. dos (2015) Os direitos fundamentais em Timor-Leste: Teoria e prática [Fundamental rights in Timor-Leste: Theory and practice], Coimbra: Coimbra Editora.

Plessis, J. du and Leckie, S. (2000) Housing, property and land rights in East Timor: Proposals for an effective dispute resolution and claim verification mechanism, UN Habitat.

Provedoria dos Direitos Humanos e Justiça (2016) 'Resultado monitorização da PDHJ sobre a implementação do projeto do alargamento das estradas e irrigação da barragem da Ribeira de Tono em RAEOA' ['PDHJ monitoring results on the implementation of the road widening project and Tono River dam irrigation project in RAEOA'], 13 June.

Radin, M. J. (1994) Reinterpreting property, Chicago: University of Chicago. doi.org/10.7208/chicago/9780226702292.001.0001.

Reeves, W. H. (1969) “"Expropriation,” "confiscation,” and "nationalization”: What one can do about them', The Business Lawyer, vol. 24, no. 3, pp. 867-886.

Ronen, Y. (2013) Transition from illegal regimes underinternational law, Cambridge: Cambridge Books Online. doi.org/10.1017/cbo9780511978142.

Rose, M. (2016) ZEESM: Destructive 'development' in Timor's special economic zone, SSGM In Brief 2016/4, Canberra: State, Society \& Governance in Melanesia, ANU. Available at: bellschool.anu.edu.au/sites/default/files/ publications/attachments/2016-04/ib-2016-4-rose_12.pdf.

Timor Post (2015a) Uma kain 270 afeitadu ba projetu ZEESM' ['270 households affected by ZEESM project'], 12 October.

Timor Post (2015b) 'ZEEMS konsege sulan komunidade iha lona okos' ['ZEESM managed to house the community under canvas shelters'], 18 October.

Vasconcelos, P. C. B. de (ed.) (2011) Constituiçâo anotada da República Democrática de Timor-Leste [Annotated Constitution of the Democratic Republic of Timor-Leste], Direitos Humanos - Centro de Investigação Interdisciplinar.

Wolford, W., Borras Jr., S. M., Hall, R., Scoones, I. and White, B. (eds) (2013) Governing global land deals: The role of the state in the rush for land, Milton, QLD: Wiley-Blackwell (Kindle version). doi.org/10.1002/9781118688229.

ZEESM (2013-2014) Oecusse Special Economic Zones of Social Market - First steps towards a new Oecusse, La'o Hamutuk - The Timor-Leste Institute for Development Monitoring and Analysis. Available at: www.laohamutuk.org/ econ/Oecussi/ZEESMSituationAnalysisMar14en.pdf. 
This text is taken from The Promise of Prosperity: Visions of the Future in Timor-Leste, edited by Judith Bovensiepen, published 2018 by ANU Press, The Australian National University, Canberra, Australia.

doi.org/10.22459/PP.2018.05 